\title{
Penerapan nilai-nilai pendidikan ekonomi keluarga dalam sektor bisnis UMKM di masa pandemi
}

\author{
Rohmawati Nurlaila, Agung Haryono* \\ Universitas Negeri Malang, Jl. Semarang No. 5 Malang, Jawa Timur, Indonesia \\ *Penulis korespondensi, Surel: agung.haryono.fe@um.ac.id
}

Paper received: 6-8-2021; revised: 20-8-2021; accepted: 28-8-2021

\begin{abstract}
Economics education of family is part of informal education which is done unprogrammed. Economics education of family is very important to be given to children to make them effective, efficient, and rational human beings in managing finances and utilizing existing resources. The purpose of this study was to determine the values of family economic education through family financial management, provision of pocket money, saving habits and living frugally, child consumption, and entrepreneurial spirit which is applied by families of MSMEs in Rejoso Hamlet, Junrejo Village, Junrejo District, Batu City. This study used a descriptive qualitative approach with a case study research type. The data collection stage includes observation, interviews, and documentation. The result of this research is that family financial management during the pandemic depends on the running business of the family, giving pocket money to children during the pandemic is carried out using a "need to ask" system. During the pandemic, the informant's child was saved from helping their parents' businesses. In terms of consumption, the informant's child has his expenditure record for each expenditure made. Informants also invite children to take part in the work of parents and involve children in family businesses and provide salaries to children like employees in general.
\end{abstract}

Keywords: economics education of family; MSMEs actors; MSMEs business

\begin{abstract}
Abstrak
Pendidikan ekonomi keluarga merupakan bagian dari pendidikan informal yang dilaksanakan secara tidak terprogram. Pendidikan ekonomi keluarga sangat penting diberikan kepada anak untuk menjadikan anak sebagai manusia yang efektif, efisien dan rasional dalam mengelola keuangan dan memanfaatkan sumber daya yang ada. Tujuan penelitian ini adalah untuk mengetahui nilai-nilai pendidikan ekonomi keluarga melalui pengelolaan keuangan keluarga, pemberian uang saku, kebiasaan menabung \& hidup hemat, konsumsi anak, dan semangat wirausaha yang diterapkan keluarga pelaku UMKM di Dusun Rejoso, Desa Junrejo, Kecamatan Junrejo, Kota Batu. Penelitian ini menggunakan pendekatan kualitatif deskriptif dengan jenis penelitian studi kasus. Tahap pengumpulan data meliputi, observasi, wawancara dan dokumentasi. Hasil penelitian ini adalah pengelolaan keuangan keluarga pada masa pandemi tergantung pada usaha yang dijalankan, pemberian uang saku kepada anak pada masa pandemi dilakukan dengan sistem "butuh minta". Pada masa pandemi, anak informan menabung dari hasil membantu usaha orang tua. Dalam hal berkonsumsi, anak informan memiliki catatan pengeluaran sendiri untuk setiap pengeluaran yang dilakukan. Informan juga mengajak anak untuk ikut serta dalam pekerjaan orang tua serta melibatkan anak dalam usaha keluarga dan memberikan gaji kepada anak seperti karyawan pada umumnya.
\end{abstract}

Kata kunci: pendidikan ekonomi keluarga; masyarakat pelaku UMKM; bisnis UMKM

\section{Pendahuluan}

Pandemi Covid-19 memberikan pengaruh yang cukup besar terhadap segala aspek kehidupan. Salah satu dampak yang ditimbulkan dan dirasakan oleh suatu negara termasuk Indonesia yaitu dalam bidang ekonomi. Terhambatnya kegiatan ekonomi dapat memberikan 
pengaruh terhadap pendapatan di suatu negara. Salah satu sektor yang terdampak yaitu UMKM di Indonesia. Seperti yang kita ketahui bahwa UMKM memberikan kontribusi yang cukup besar terhadap pembangunan roda perekonomian di Indonesia. Berdasarkan data dari kementerian koperasi bahwa terdapat 1.785 koperasi dan 163.713 pelaku Usaha Mikro Kecil dan Menengah (UMKM) yang terdampak pandemi virus korona. Selain minuman dan makanan, sektor UMKM lainnya yang terguncang ialah industri kreatif dan juga pertanian. Seperti di Kampung UMKM yang terletak di Jalan Trunojoyo RT 03/RW 10, Dusun Rejoso, Desa Junrejo, Kecamatan Junrejo, Kota Batu, Jawa Timur. Kampung UMKM ini sudah berdiri sejak lama. Di Dusun Rejoso ini terdapat banyak sekali Sentra UMKM mulai dari makanan, perabotan rumah tangga, perabotan kayu, souvenir dan masih banyak lagi. Dalam proses pengembangannya, UMKM memang menjadi sorotan dan mendapat banyak perhatian dari pemerintah. Meskipun demikian, permasalahan pelaku UMKM ini tidak kunjung selesai. Menurut salah satu penduduk di kampung UMKM yaitu Affan Rizqyawan Yafi, masih terdapat beberapa kendala yang perlu diatasi, salah satunya dari segi pendanaan. Pendanaan termasuk hal yang sangat penting bagi pelaku-pelaku usaha untuk memulai bisnis dan mengembangkan usaha. Pelaku-pelaku usaha tidak bisa menjalankan usahanya tanpa bantuan modal dari pemerintah desa ataupun pemerintah kota. Apalagi di masa pandemi seperti saat ini, masalah yang dihadapi pelaku UMKM di kampung UMKM ini semakin kompleks, mulai dari pendanaan, pemasaran produk dan pengelolaan keuangan. Secara tidak langsung hal tersebut akan mempengaruhi pendapatan yang diperoleh masyarakat sekitar.

Dari berbagai masalah tersebut, pendidikan ekonomi keluarga ini sangat diperlukan untuk dapat mengatasi berbagai permasalahan ekonomi yang terjadi. Rendahnya tingkat pendidikan maupun pengetahuan tentang pendidikan ekonomi di masyarakat secara tidak langsung akan berpengaruh terhadap kondisi ekonomi di dalam keluarga pelaku UMKM. Melalui pendidikan ekonomi di dalam keluarga, secara tidak langsung akan membentuk manusia yang produktif dan ekonomis dalam memanfaatkan sumberdaya yang ada. Seperti yang dikemukakan oleh Ayuningtias (2014) bahwa keluarga merupakan lingkungan pengenalan pertama dan merupakan unit utama bagi seorang anak. Segala macam proses pembelajaran yang diterapkan di lingkungan keluarga, seperti etika, tata krama, sosial maupun ekonomi, orang tua sangat berperan sebagai pendidik sebelum mereka terjun ke lingkungan sekolah. Dalam keseharian, sikap dan tindakan orang tua dapat memberikan gambaran terhadap bagaimana anak bertingkah laku. Didikan orang tua yang kurang tepat dapat mengakibatkan anak tidak mandiri dan sulit menyesuaikan diri dengan lingkungannya. Sebagai orang tua, wajib memberikan proses pembelajaran yang baik agar anak dapat mencontohnya dengan baik pula. Orang tua juga harus mengajarkan anak untuk mengelola keuangan dengan baik. Anak harus mulai diajarkan bagaimana mengelola uang dan menggunakannya sesuai dengan kebutuhan agar anak tidak boros dan dapat membedakan antara kebutuhan primer, sekunder dan tersier. Berdasarkan pernyataan dari Vito (2013) yang menyatakan bahwa pendidikan ekonomi sudah seharusnya diajarkan di lingkungan keluarga sejak dini. Bentuk-bentuk pendidikan ekonomi yang bisa diajarkan sejak dini misalnya seorang anak yang sudah diajarkan untuk menabung, hidup hemat dan dapat memenuhi kebutuhannya sendiri. Proses pendidikan ekonomi yang terjadi di lingkungan keluarga difokuskan pada pemahaman mengenai pengelolaan keuangan keluarga dan juga pada sikap serta perilaku anak. Pemahaman tersebut bertujuan agar anak dapat memanfaatkan uang sesuai dengan prinsip ekonomi yang rasional. 
Menurut (Muhammad, 2016) proses pendidikan ekonomi di lingkungan keluarga berupa pengalaman dalam kegiatan ekonomi yang dapat ditanamkan kepada anak dengan membiasakan anak untuk menggunakan uang dengan baik. Dengan memberikan pengetahuan tentang pengelolaan keuangan, maka terdapat beberapa hal positif terkait dengan membelanjakan, menabung, serta menginvestasikan uang dengan benar. Orang tua dapat mengajarkan pendidikan ekonomi kepada anak dengan cara-cara sederhana. Seperti yang dikatakan oleh Widayati (2012:92) bahwa melalui cara-cara sederhana yang diajarkan oleh orang tua melalui pendidikan ekonomi keluarga, secara tidak langsung akan membawa anak kepada sikap hidup yang diinginkan. Keteladanan yang orang tua contohkan juga secara tidak langsung sudah membawa anak kepada kebiasaan yang tentunya lebih baik. Pendidikan ekonomi keluarga ini sangat diperlukan agar keluarga dapat mencapai titik kesejahteraan dan jauh dari garis kemiskinan apalagi pada saat pandemi seperti saat ini.

Dari berbagai permasalahan tersebut maka penulis tertarik untuk melakukan penelitian di Dusun Rejoso, Desa Junrejo, Kecamatan Junrejo, Kota Batu. Penulis ingin meneliti apakah nilai-nilai pendidikan ekonomi keluarga diterapkan dengan baik di kampung UMKM dalam kondisi normal ataupun pada saat pandemi. Peneliti ingin mengetahui sejauh mana keluarga di Kampung UMKM dalam mengelola keuangan keluarga agar tetap bisa memenuhi kebutuhan hidup sehari-hari terutama pada saat pandemi. Bagaimana keluarga mengelola pendapatan yang diperoleh dari hasil usahanya untuk kebutuhan sehari-hari. Selain itu bagaimana orang tua dalam keluarga berperan untuk mendidik dan menanamkan nilai-nilai pendidikan ekonomi kepada anak-anak mereka seperti menanamkan kebiasaan menabung dan hidup hemat, mengontrol konsumsi anak, pengelolaan uang saku, dan menanamkan semangat berwirausaha pada saat pandemi. Yulianti dan Silvy (2013) Hilgret \& Jeanne menyatakan bahwa untuk mencapai manajemen keuangan keluarga yang baik dibutuhkan keputusan keuangan yang baik dan benar. Manajemen keuangan keluarga dapat dilakukan dengan mengelola pengeluaran, meningkatkan pendapatan dan melakukan pembayaran pajak dengan baik. Yulianti dan Silvy (2013) dalam penelitiannya juga menyatakan bahwa pengetahuan tentang pengelolaan keuangan berpengaruh terhadap perencanaan investasi keuangan yang ada dalam keluarga. Seperti halnya pengelolaan keuangan keluarga, pemberian uang saku juga merupakan hal wajib yang harus diberikan kepada anak. Pemberian uang saku kepada anak bisa dilakukan setiap hari, setiap minggu atau setiap bulan tergantung pada kebijakan yang orang tua berikan. Marteniawati (2012) mengemukakan bahwa uang saku adalah uang yang diberikan oleh orang tua kepada anak yang digunakan untuk memenuhi kebutuhan yang diperlukan oleh para pelajar seperti makanan, kos, pakaian, buku, dan lain sebagainya. Tujuan pemberian uang saku yaitu sebagai proses pembelajaran bagi anak agar dapat mengelola keuangan dengan baik. Begitupun dengan kebiasaan menabung dan hidup hemat. Menurut Kamus Besar Bahasa Indonesia (2015), menabung adalah kegiatan menyimpan uang dalam celengan dan juga bank. Melalui menabung seseorang bisa belajar untuk mengelola keuangannya sendiri dan tidak boros. Orang tua juga berperan dalam mengontrol konsumsi anak terutama jika anak sudah menginjak remaja. Konsumsi anak yang berlebihan dapat menjadikan anak berperilaku konsumtif. Perilaku konsumtif ini tentunya tergantung pada bagaimana orang tua mendidik anak mereka. Seperti pernyataan Alam (2013:46) Dalam ilmu ekonomi, "konsumsi adalah suatu kegiatan menghabiskan manfaat suatu benda baik itu barang atau jasa yang bertujuan untuk memenuhi kebutuhan hidup sehari-hari."

Pendidikan ekonomi yang diterapkan di lingkungan keluarga bukan hanya sekedar mengelola keuangan keluarga. Namun, memiliki karakteristik yang lebih luas daripada itu. 
Misalnya saja proses keluarga dalam belajar kewirausahaan, adanya komunikasi dan tanggung jawab antar anggota keluarga dalam penggunaan anggaran keluarga, peran istri dalam keluarga dan bagaimana membentuk perilaku anggota keluarga yang sesuai dengan perilaku ekonomi yang baik. Seperti halnya dalam hal kewirausahaan yang memang harus ditanamkan oleh keluarga pelaku UMKM di kampung UMKM. Para pelaku UMKM harus memiliki jiwa kewirausahaan sebagai upaya untuk mengasah kemampuan diri agar dapat meningkatkan kesejahteraan hidup. Seseorang yang memiliki jiwa wirausaha akan memiliki kreatifitas dan rasa tanggung jawab yang besar dan tentunya bisa mengambil peluang bisnis untuk dapat dikembangkan.

Terdapat beberapa sifat seorang wirausaha yang dapat dilatih sejak dini dalam lingkungan keluarga maupun masyarakat. Menurut Harsono (2015) sifat tersebut antara lain; berani mengambil resiko, tanggung jawab, dan belajar menginspirasi (mempunyai kreatifitas). Sehingga pandemi seharusnya tidak menjadi penghalang untuk tetap dapat bekerja dan memenuhi kebutuhan sehari-hari.

Dari berbagai kondisi di atas, tujuan adanya penelitian ini yaitu untuk mengetahui bagaimana cara orang tua dalam mengelola keuangan keluarga di kampung UMKM, bagaimana pola pemberian uang saku di saat pandemi (sekolah online), kebiasaan menabung \& hidup hemat dan konsumsi anak yang diterapkan orangtua kepada anak, serta bagaimana cara pengembangan semangat kewirausahaan yang dilakukan orangtua kepada anak. Kondisi masyarakat yang sudah produktif harus tetap dijaga dan dilestarikan, karena selain wujud dari melestarikan budaya, sektor bisnis UMKM dapat meningkatkan kesejahteraan masyarakat. Pendidikan ekonomi dalam keluarga dapat terus diperbaiki untuk generasi selanjutnya. Tak lupa juga peran pemerintah sangat diperlukan agar kampung UMKM ini semakin berkembang.

\section{Metode}

Penelitian ini dimaksudkan untuk mendapatkan gambaran mengenai penerapan nilainilai pendidikan ekonomi keluarga di kampung UMKM. Dalam tahap perencanaan diawali dengan menentukan topik penelitian kemudian mencari sumber-sumber data dari berbagai artikel, buku-buku akademik, jurnal ilmiah pada laman internet dengan sumber yang dapat dipertanggungjawabkan sesuai dengan fokus penelitian. Metode yang digunakan pada penelitian ini yaitu metode kualitatif, dimana metode kualitatif ini menyajikan hubungan antara peneliti dan informan secara langsung. Dalam penelitian ini, peneliti melakukan observasi dan wawancara secara langsung kepada informan (masyarakat pelaku UMKM) yang dilakukan pada bulan Februari - Maret 2021. Data yang diperoleh di lapangan nantinya berupa fakta yang perlu dianalisis secara mendalam. Jenis penelitian yang digunakan dalam penelitian ini yaitu studi kasus. Sumber data yang digunakan dalam penelitian ini adalah data primer berupa hasil wawancara secara mendalam (transkrip hasil wawancara dan hasil temuan pada saat penelitian berlangsung) dan data sekunder yang didapat dari literatur-literatur dan studi pustaka yang berkaitan dengan penelitian seperti dari buku di perpustakaan dan jurnal pendukung lainnya.

Instrumen yang digunakan dalam penelitian ini yaitu pedoman observasi, pedoman wawancara dan dokumentasi. Pedoman observasi meliputi ruang atau tempat, pelaku, kegiatan, waktu, dan peristiwa. Melalui wawancara, peneliti mempersiapkan beberapa pertanyaan yang dijadikan acuan untuk mendapatkan informasi dalam penelitian. Sedangkan melalui dokumentasi peneliti menyiapkan buku, ballpoint, dan telepon genggam yang 
digunakan untuk recorder dan foto/video. Teknik atau cara peneliti dalam mengumpulkan data yaitu melalui observasi yang dilakukan melalui pengamatan langsung berkaitan dengan nilai-nilai pendidikan ekonomi yang diterapkan dalam keluarga pelaku UMKM di Jalan Trunojoyo RT 03/RW 10, Dusun Rejoso, Desa Junrejo, Kecamatan Junrejo, Kota Batu, Jawa Timur. Selanjutnya yaitu proses wawancara yang dilakukan peneliti secara mendalam di masyarakat yang mempunyai industri terutama industri makanan, perabotan rumah tangga, alat pijat refleksi dan tas plastik. Teknik wawancara yang digunakan peneliti bersifat open ended, fleksibel dan terstruktur. Selanjutnya dokumentasi yang dilakukan peneliti yaitu melalui foto atau rekaman video ketika observasi dan wawancara berlangsung serta dokumentasi yang berkaitan dengan data penelitian.

Analisis data yang digunakan peneliti dalam penelitian ini adalah metode deskriptif analitik, dimana data yang dikumpulkan nantinya berupa kata-kata, gambar dan bukan angka. Teknik analisis data yang digunakan peneliti meliputi pengumpulan data, reduksi data, penyajian data, dan penarikan kesimpulan. Sedangkan untuk menguji keabsahan data, peneliti menggunakan teknik triangulasi sumber. Teknik uji keabsahan lain yang digunakan oleh peneliti adalah perpanjangan waktu keikutsertaan. Dalam melakukan penelitian, peneliti melalui beberapa tahapan dalam penelitian. Tahap-tahap penelitian yang dilakukan oleh peneliti ada empat yaitu tahap pra lapangan, tahap pekerjaan lapangan, tahap analisis data, dan tahap evaluasi dan pelaporan.

\section{Hasil dan Pembahasan}

\subsection{Hasil}

Peneliti telah melakukan wawancara dan observasi langsung secara mendalam dengan empat informan yang memiliki berbagai usaha di kampung UMKM. Diantaranya; usaha makanan, perabot rumah tangga, tas plastik dan alat pijat refleksi. Penerapan nilai-nilai pendidikan ekonomi dalam setiap keluarga pelaku UMKM tentunya memiliki perbedaan. Hal ini dikarenakan penghasilan yang diperoleh keluarga dalam menjalankan usaha selain digunakan untuk memenuhi kebutuhan sehari-hari juga digunakan untuk memenuhi kebutuhan produksi. Selain itu, setiap keluarga memiliki cara yang berbeda dalam pengelolaan keuangan keluarga, pemberian uang saku, kebiasaan menabung dan hidup hemat, konsumsi anak dan semangat berwirausaha.

Dari keempat informan dapat disimpulkan bahwa para informan memperoleh penghasilan dari kegiatan usaha yang dijalankan. Penghasilan yang diperoleh informan digunakan untuk memenuhi kebutuhan keluarga dan kebutuhan produksi (modal usaha). Cara pengelolaan keuangan keluarga dari masing-masing informan juga berbeda dilihat dari penghasilan yang diperoleh setiap bulannya, termasuk besar kecilnya usaha yang dimiliki meskipun pada saat pandemi semua pendapatan dari informan 001-004 menurun drastis. Seperti yang dikatakan informan 001 dan 003 bahwa pandemi memberikan dampak yang cukup besar terhadap perkembangan usaha pelaku UMKM. Pendapatan yang diperoleh sangat minim untuk mencukupi kebutuhan hidup sehari-hari. Berbeda dengan informan 002 dan informan 004. Dimana usaha yang mereka miliki sudah dikategorikan sebagai usaha menengah sampai besar. Sehingga pandemi tidak menjadi penghalang untuk terus berproduksi dan penghasilan yang diperoleh sangat cukup untuk memenuhi kebutuhan hidup sehari-hari. Setiap keluarga mempunyai catatan pembukuan tersendiri berupa pemasukan dan 
pengeluaran setiap hari, setiap minggu dan setiap bulan. Begitupun dengan jumlah pengeluaran rumah tangga juga berbeda tergantung dari kebutuhan masing-masing keluarga, jumlah anak dan penghasilan yang diperoleh.

Seperti halnya pengelolaan keuangan dalam keluarga, pemberian uang saku, kebiasaan menabung, hidup hemat dan konsumsi anak di setiap keluarga pelaku UMKM juga berbeda. Pemberian uang saku kepada anak pada masa pandemi dilakukan dengan sistem "butuh minta". Dalam hal ini orang tua tetap memberikan uang saku kepada anak, namun jumlah yang diberikan tidak seperti biasanya. Ada pengurangan jumlah uang saku yang diberikan. Selebihnya anak akan meminta sendiri ketika membutuhkan untuk membeli paketan atau untuk jajan dirumah. Jumlah nominal uang saku yang diberikan sesuai dengan penghasilan yang diterima informan. Empat informan memberikan uang saku setiap hari kepada anak dengan jumlah yang lebih sedikit karena beranggapan bahwa memberikan jatah uang saku kepada anak terutama pada saat pandemi adalah kewajiban orang tua meskipun jumlahnya sedikit atau menurun dari biasanya. Uang saku tersebut biasanya digunakan anak untuk membeli paketan yang digunakan untuk sekolah online. Dalam hal menabung dan hidup hemat, orang tua selalu mengajarkan anak untuk menabung dari sisa uang saku dan dari hasil kerja membantu usaha orang tua. Pada masa pandemi, anak informan menabung dari hasil membantu usaha orang tua dikarenakan mereka tidak mendapatkan uang saku secara penuh ketika belajar di rumah. Sehingga uang yang di dapat hanya cukup untuk membeli paketan dan jajan sehari-hari.

Dari segi berkonsumsi berdasarkan pernyataan yang disampaikan oleh keempat informan dapat disimpulkan bahwa semua informan mengajarkan anak mereka untuk mandiri dan tidak boros dalam berkonsumsi. Anak informan memiliki cara tersendiri untuk mengelola pengeluaran keuangan masing-masing. Anak informan sudah diajarkan untuk membuat pembukuan mengenai pengeluaran yang dilakukan setiap hari mulai dari jajan, bensin, paketan dan kebutuhan tak terduga lainnya. Pada saat pandemi, anak informan lebih mengutamakan pengeluaran untuk membeli paketan daripada konsumsi yang tidak perlu. Informan sebagai orang tua juga mengajak anak untuk membantu pekerjaan orang tua sebagai upaya mengembangkan semangat kewirausahaan kepada anak. Semua informan sudah melibatkan anak dalam usaha keluarga. Satu dari empat informan bahkan memberikan gaji kepada anak seperti halnya karyawan yang lainnya. Satu dari empat informan bahkan mengajarkan anak untuk disiplin dan tanggung jawab sebelum memegang usaha sendiri dengan memperkerjakan anak ke orang lain dan memberikan gaji. Namun, para informan juga tidak memaksakan keinginan anak untuk menjadi pengusaha atau meneruskan bisnis keluarga. Informan sebagai orang tua hanya dapat memberikan skill dan jiwa entrepreneur sebagai bekal anaknya dalam mencari pekerjaan kelak.

\subsection{Pembahasan}

Setelah proses penulisan paparan data berupa hasil dan beberapa temuan penelitian yang ditemukan peneliti pada saat observasi, wawancara dan dokumentasi berlangsung, maka selanjutnya peneliti akan menganalisis data yang telah terkumpul. Hal ini dilakukan agar peneliti dapat mengambil kesimpulan sesuai dengan fokus penelitian. Penelitian ini menggunakan analisis deskriptif kualitatif yaitu memaparkan data yang diperoleh selama proses observasi, wawancara, dan dokumentasi dari informan yang terlibat dalam penelitian 
ini. Setelah dianalisis, hasil analisis tersebut dikaitkan atau diperbandingkan dengan teori yang ada diantaranya sebagai berikut:

\subsubsection{Penerapan Nilai-Nilai Pendidikan Ekonomi Keluarga Melalui Pengelolaan Keuangan Keluarga}

Mengenai pengelolaan keuangan keluarga telah dijelaskan sebelumnya bahwa pengelolaan keuangan keluarga didefinisikan sebagai tindakan keluarga dalam mengelola keuangan dari pemasukan yang diterima guna tercapainya suatu tujuan finansial di masa yang akan datang. Pengelolaan keuangan merupakan bagian penting dalam mengatasi berbagai masalah ekonomi, baik masalah individu, keluarga ataupun perusahaan. Pengelolaan keuangan yang ada di dalam keluarga memiliki peran penting dalam menjaga keharmonisan keluarga. Hal tersebut juga akan meminimalisir adanya masalah yang timbul dalam rumah tangga. Menurut Bank Indonesia (2015) di dalam pengelolaan keuangan keluarga terdapat langkahlangkah yang perlu dilakukan agar pengelolaan keuangan keluarga berjalan dengan baik, yaitu sebagai berikut: Pencatatan semua harta yang dimiliki, pencatatan pemasukan dan pengeluaran secara rutin, menggolongkan dan mencatat pengeluaran rutin, bulanan, dan tahunan setiap keluarga, menyusun rencana pengeluaran (budgeting), dan menyisakan harta untuk ditabung (menabung secara periodik).

Melalui beberapa tahap yang sudah dilakukan oleh peneliti berupa wawancara, observasi dan dokumentasi, peneliti berhasil menemukan data temuan yang diantaranya adalah: Pertama, informan memperoleh penghasilan dari kegiatan usaha yang dijalankan. Kedua, penghasilan yang diperoleh informan digunakan untuk memenuhi kebutuhan keluarga dan modal usaha. Ketiga, pendapatan dan pengeluaran setiap keluarga berbeda tergantung dari kondisi internal keluarga dan lancar tidaknya bisnis yang dijalankan. Keempat, setiap keluarga mempunyai catatan pembukuan tersendiri untuk seluruh pemasukan dan pengeluaran. Kelima, orang tua terbuka mengenai keuangan keluarga kepada anak-anak.

Dari hasil yang ditemukan peneliti di lapangan, sebagian terdapat kesinambungan dengan landasan teori yang peneliti rangkai, namun sebagian lagi tidak sesuai dengan landasan teori yang ada. Hal ini dikarenakan beberapa keluarga di kampung UMKM belum sepenuhnya menerapkan pengelolaan keuangan dengan baik seperti pencatatan semua aset atau harta yang dimiliki secara berkelanjutan dan menabung secara periodik. Namun, sebagian keluarga sudah melakukan pencatatan keuangan dengan baik seperti pencatatan semua pemasukan dan pengeluaran, pencatatan pengeluaran rutin dan bulanan setiap keluarga, serta menyusun rencana pengeluaran (budgeting). Meskipun setiap keluarga sudah melakukan pembukuan atau pencatatan pengeluaran dan pemasukan dari hasil usahanya. Namun hal tersebut belum dilakukan secara maksimal. Informan hanya mencatat seadanya dan tidak terperinci. Seringkali masih ada pengeluaran yang tidak tercatat dan akhirnya minus untuk kegiatan produksinya. Hal ini mungkin disebabkan karena kebanyakan pelaku UMKM kurang maksimal bahkan tidak menyiapkan anggaran keuangan dengan baik di dalam manajemen usaha yang mereka miliki. Hal ini terbukti berdasarkan survei yang dilakukan oleh Raharjo dan Wirjono (2012), yang menyatakan bahwa kesadaran pelaku UMKM untuk membuat pembukuan terkait dengan perencanaan anggaran, pelaksanaan sampai pada pengendalian dalam keuangannya masih sangat rendah. Bahkan beberapa pelaku UMKM bisa dikatakan tidak pernah membuat pembukuan apapun terkait dengan manajemen usahanya. Padahal melakukan pembukuan di 
dalam usaha sangatlah penting untuk perkembangan usaha yang dimiliki sehingga para pelaku UMKM sudah seharusnya mendapatkan edukasi yang lebih lanjut.

Yulianti dan Silvy (2013) Hilgret \& Jeanne menyatakan bahwa untuk mencapai manajemen keuangan keluarga yang baik dibutuhkan keputusan keuangan yang baik pula. Hal tersebut bertujuan untuk meningkatkan pendapatan dalam keluarga, mengelola pengeluaran yang terjadi dan pembayaran pajak. Hal tersebut sangat dibutuhkan dan sudah seharusnya diterapkan dalam keluarga pelaku UMKM. Berdasarkan pemaparan keempat informan yang peneliti wawancara, pengelolaan keuangan keluarga pada masa pandemi tergantung pada usaha yang dijalankan. Jika jumlah pendapatan yang diperoleh dari hasil penjualan masih tergolong tinggi, maka akan lebih mudah bagi keluarga terutama seorang istri untuk mengelola keuangan keluarga. Setiap pendapatan juga selalu dibagi dengan kebutuhan produksi. Jadi tidak serta merta untuk kebutuhan sehari-hari. Jumlah pengeluaran setiap bulannya berbedabeda tergantung pada kondisi internal keluarga dan pasang surutnya usaha yang dijalankan.

Hal yang perlu diketahui juga bahwa di dalam pengelolaan keuangan keluarga, tingkat pendidikan anggota keluarga ternyata tidak terlalu berpengaruh terhadap baik buruknya pengelolaan keuangan di dalam keluarga. Hal tersebut dikarenakan pengelolaan keuangan bisa dipelajari oleh siapapun yang memang berkeinginan untuk belajar dan mempunyai kesadaran dalam mengelola keuangan dengan baik terlepas dari tingkat pendidikan yang ditempuh. Hal tersebut sesuai dengan hasil penelitian yang dilakukan oleh Andrew dan Linawati (2014) yang menemukan bukti bahwa tingkat pendidikan tidak mempunyai pengaruh yang signifikan terhadap perilaku keuangan, sebaliknya jenis kelamin, tingkat pendapatan dan pengetahuan keuangan mempunyai hubungan yang signifikan terhadap perilaku keuangan di dalam anggota keluarga. Begitupun dengan tingkat pendapatan. Dari hasil penelitian, keluarga cenderung dapat mengelola keuangan dengan baik jika memperoleh pendapatan yang besar dan akan sulit mengatur keuangannya jika pendapatan yang diperoleh dibawah rata-rata. Bahkan pendapatan informan yang diperoleh pada saat pandemi sangat minim untuk ditabung dan hanya cukup untuk kebutuhan sehari-hari serta produksi. Semakin tinggi pendapatan pelaku UMKM secara tidak langsung juga akan meningkatkan pengetahuan dan pemahaman tentang pengelolaan keuangan yang baik. Hal tersebut juga sesuai dengan hasil penelitian Mahdzan dan Tabiani Dalam Andrew dan Linawati (2014) yang menyatakan bahwa besar kecilnya pendapatan akan berpengaruh terhadap pengetahuan dan pemahaman keuangan anggota keluarga. Semakin tinggi pendapatan yang diperoleh seseorang, maka orang tersebut akan berusaha memperoleh pengetahuan dan pemahaman tentang bagaimana cara menggunakan dan memanfaatkan keuangan dengan cara yang lebih baik.

Dalam kehidupan rumah tangga, setiap keluarga pasti menginginkan masa depan yang sejahtera dan bahagia. Salah satu faktor pendukung keluarga yang sejahtera adalah dalam hal kesuksesan finansial. Hal tersebut sesuai dengan pernyataan Widayati (2012) yang menyatakan bahwa kecerdasan finansial adalah kecerdasan yang dimiliki oleh seseorang (biasanya di dalam rumah tangga istri yang paling dominan) dalam mengelola keuangan keluarga. Penerapan pengelolaan keuangan yang baik di dalam keluarga akan menjadikan keluarga mendapatkan manfaat yang maksimal dari uang/harta yang dimilikinya. Sehingga diharapkan keluarga dapat mencapai titik kesejahteraan dalam memenuhi kebutuhan hidup sehari-hari. 


\subsubsection{Penerapan Nilai-nilai Pendidikan Ekonomi Keluarga Melalui Pemberian Uang Saku, Kebiasaan Menabung, Hidup Hemat dan Konsumsi Anak}

\subsubsection{Pemberian Uang Saku}

Pemberian uang saku kepada anak bertujuan agar anak dapat mandiri dalam mengelola keuangannya. Selain itu agar anak dapat dengan bijak menggunakan uang baik itu yang diberikan secara harian atau mingguan. Pemberian uang saku kepada anak pada masa pandemi dilakukan dengan sistem "butuh minta". Dalam hal ini orang tua tetap memberikan uang saku kepada anak namun jumlah yang diberikan tidak seperti biasanya. Terdapat pengurangan jumlah uang saku yang diberikan. Uang saku harian yang diberikan kepada anak Sekolah Dasar berkisar Rp5.000,00 sampai Rp10.000,00 (pada saat pandemi hanya Rp5.000,00 saja). Uang Saku Harian yang diberikan kepada anak Sekolah Menengah Pertama (SMP) berkisar Rp10.000,00 sampai Rp20.000,00 (pada saat pandemi hanya Rp5.000,00 saja). Uang Saku Harian yang diberikan kepada anak Sekolah Menengah Atas (SMA) berkisar Rp15.000,00 sampai Rp25.000,00 (pada saat pandemi hanya Rp10.000,00 saja). Selebihnya anak akan meminta sendiri ketika membutuhkan untuk membeli paketan atau untuk keperluan jajan sehari-hari.

Uang saku merupakan uang tambahan yang diberikan oleh orang tua kepada anaknya untuk keperluan pendidikan dan kebutuhan sehari-hari. Uang saku yang diberikan sudah termasuk uang jajan, keperluan sekolah, dan juga bensin. Tetapi terkadang untuk bensin ada jatah tersendiri. Tujuan pemberian uang saku ini sebenarnya agar anak dapat mandiri dan percaya diri dalam mengelola keuangannya sendiri. Hadley (2011) mengatakan bahwa pemberian uang saku kepada anak menjadi salah satu cara orang tua untuk mendidik atau mengajarkan kepada anak mengenai tanggungjawab dalam mengelola keuangannya sendiri. Orang tua mengajarkan tentang nilai uang (fungsi dan manfaat uang) sehingga anak memiliki kesadaran untuk bertanggung jawab dalam penggunaan uang tersebut. Orang tua hanya memberikan nasehat agar uang saku yang diterima anak dapat mencukupi kebutuhan seharihari yang diperlukan. Jika uang saku yang diberikan tidak cukup dikarenakan ada kebutuhan yang mendesak maka orang tua akan memberikan tambahan uang saku. Hal tersebut juga sejalan dengan pernyataan Lermitte (Ardiana, 2016:64) yang menjelaskan bahwa pemberian uang saku kepada anak merupakan bukti kepercayaan orang tua yang diberikan kepada anak. Sebagai orang tua harus memberikan contoh yang baik dan harus memberikan kepercayaan kepada anak agar anak juga memiliki rasa tanggung jawab.

Dari penelitian yang dilakukan peneliti, empat informan memberikan uang saku sesuai dengan penghasilan yang diterima informan dan disesuaikan dengan kebutuhan anak di sekolah. Pada saat pandemi, orang tua tetap memberikan jatah uang saku karena beranggapan bahwa memberikan jatah uang saku kepada anak adalah kewajiban orang tua meskipun jumlahnya sedikit atau menurun dari biasanya. Setiap orang tua memiliki cara tersendiri dalam memberikan uang saku kepada anak, namun orang tua juga perlu mengontrol uang saku yang sudah diberikan. Seorang anak juga harus dapat mempergunakan uang saku dengan sebaik mungkin. Dari penelitian yang sudah diteliti, anak informan dapat mempergunakan uang saku dengan sebaik mungkin sesuai arahan dari orang tuanya, baik itu usia SMP atau SMA. Uang saku yang diterima biasanya untuk membeli paketan yang digunakan untuk belajar di rumah. Sedangkan untuk membeli jajan, anak informan akan meminta ketika membutuhkan. Hal tersebut sejalan dengan penelitian Vhalery, Leksono, et al. (2019) bahwa ada beberapa faktor 
yang mempengaruhi pengelolaan uang saku diantaranya pengetahuan keuangan (literasi keuangan) dan usia yang merupakan faktor internal, sedangkan bimbingan orang tua yang merupakan faktor eksternal.

\subsubsection{Kebiasaan Menabung dan Hidup Hemat}

Informan sebagai orang tua mengajarkan anak untuk selalu berhemat dan menabung agar anak dapat mandiri dan memenuhi kebutuhannya sendiri. Orang tua mengajarkan anak untuk hidup hemat dan menabung dari kecil. Pada masa pandemi, anak informan menabung dari hasil membantu usaha orang tua dikarenakan mereka tidak mendapatkan uang saku secara penuh ketika belajar di rumah, sehingga uang yang di dapat hanya cukup untuk membeli paketan dan jajan sehari-hari. Hal tersebut sesuai dengan penelitian Lail (2015) yang menyatakan bahwa tujuan menabung yaitu untuk membiasakan seseorang agar dapat hidup hemat. Hidup hemat sendiri berarti tidak boros dalam pengeluaran. Pengeluaran apapun disesuaikan dengan kebutuhan yang ada.

Kegiatan menabung akan sangat bermanfaat untuk masa depan anak. Sebagai orang tua harus mampu memberikan pengertian dan pemahaman kepada anak bagaimana pentingnya menabung dan hidup hemat untuk masa depan anak. Di dalam penelitian ini para informan sudah menyediakan fasilitas untuk menabung seperti celengan dan buku tabungan. Dua informan sudah memfasilitasi anak buku tabungan untuk menabung ketika anak mendapatkan uang dari hasil membantu orang tuanya. Sebagian informan memfasilitasi anak berupa celengan agar anak informan dapat menabung dengan mudah tanpa harus ke bank. Hal ini sesuai dengan penelitian yang dilakukan oleh Brief (2012) yang berjudul Youth Financial Inclusion: Complementing Financial Education with Account Access menyimpulkan bahwa pengalaman dan pengetahuan sejak dini tentang perbankan dapat membantu anak untuk membangun kebiasaan keuangan yang baik seperti menabung dan hidup hemat. Pengetahuan dan pengalaman anak tentang perbankan dapat diperoleh dari pengenalan yang dilakukan orang tua kepada anak terhadap lembaga keuangan yang dapat melatih kontrol diri anak dan menjadikan anak memiliki rencana masa depan yang baik. Hal ini dikarenakan sekolah dan lembaga keuangan merupakan partner yang baik dalam menumbuhkan kebiasaan anak dalam menabung.

Seperti halnya penelitian yang dilakukan Rapih (2016) yang menjelaskan bahwa pengenalan menabung sejak dini dan melakukan pembiasaan terhadap anak untuk menyisihkan sebagian uang saku yang diberikan dapat menjadi kebiasaan yang penting di kemudian hari sehingga dapat bermanfaat bagi masa depan anak. Sebagai orang tua tidak cukup jika proses mendidik anak hanya dilakukan dengan menyuruh dan memerintah saja. Namun, orang tua juga harus bisa mempraktekkan arahan yang diberikan. Anak membutuhkan arahan dari orang tua untuk diterapkan dalam kehidupan sehari-hari.

\subsubsection{Konsumsi Anak}

Konsumsi adalah salah satu kegiatan ekonomi yang dapat diartikan sebagai suatu kegiatan yang dilakukan seseorang untuk mengurangi nilai suatu barang atau jasa. Tujuan seseorang melakukan konsumsi adalah untuk memenuhi kebutuhan hidup sehari-hari, sehingga dapat terus melangsungkan hidupnya. Berdasarkan pernyataan yang disampaikan oleh keempat informan dapat disimpulkan bahwa semua informan mengajarkan anak mereka untuk hemat dan tidak boros dalam berkonsumsi. Pengeluaran apapun yang dilakukan anak 
informan selalu jujur kepada informan sebagai orang tua. Dalam berkonsumsi, orang tua mempunyai kendali terhadap pengeluaran anak. Biasanya anak berkonsumsi dari uang saku yang diberikan atau dari tabungan yang dimilikinya. Namun, pada saat pandemi seperti saat ini, anak-anak informan memiliki kesadaran untuk mengurangi konsumsi yang berlebihan bahkan yang tidak perlu seperti untuk jalan-jalan, membeli baju dan lain-lain. Mereka lebih memfokuskan untuk membeli paket internet yang digunakan untuk belajar dan bermain game online.

Informan sebagai orang tua memberikan pemahaman mengenai bagaimana pekerjaan orang tua, pendapatan yang diperoleh, sehingga anak dapat mempunyai kesadaran tersendiri untuk mempergunakan uang dengan sebaik mungkin. Terutama orang tua yang memiliki anak usia remaja, yang tentunya mempunyai pengeluaran lebih besar dikarenakan banyak faktor seperti ajakan teman untuk jalan-jalan atau sekedar membeli barang-barang yang sebenarnya tidak dibutuhkan. Hal seperti itu jika tidak dikendalikan bisa menimbulkan perilaku konsumtif. Seperti pernyataan dari Siswoyo (Narmaditya, 2013:12) bahwa perilaku konsumsi yang terjadi di kalangan remaja salah satunya dipengaruhi oleh pendidikan yang diterapkan di dalam keluarga tersebut. Perilaku konsumtif dapat timbul melalui pembiasaan dan keteladanan yang dibiasakan oleh keluarga. Misalnya saja anak yang cenderung dimanjakan oleh orang tuanya. Sehingga keluarga mempunyai peran yang sangat penting untuk mengontrol konsumsi anak yang berlebih. Jangan sampai anak menjadi anak yang manja dan boros dalam berkonsumsi.

Sebagai seorang wirausaha, informan mengajarkan anak mereka untuk membuat pembukuan mengenai pemasukan dan pengeluaran yang anak informan lakukan setiap hari, setiap minggu bahkan setiap bulan. Hal tersebut bertujuan agar anak informan dapat mengendalikan segala pengeluaran yang tidak perlu serta dapat membedakan antara kebutuhan primer, sekunder dan tersier. Orang tua juga melakukan pembukuan atas pendapatan dari usaha yang didapatkan setiap bulannya beserta rincian pengeluarannya sebagai contoh yang diberikan kepada anak. Hasil penelitian ini juga sejalan dengan penelitian yang dilakukan oleh Sulaeman (2012) yang menyatakan bahwa dalam pengelolaan pribadi keuangan anak, orang tua merupakan sumber utama yang berpengaruh terhadap pengetahuan anak mengenai pengelolaan keuangan. Orang tua harus aktif memberikan pengetahuan dan pendidikan keuangan kepada anak serta memberikan pemahaman terhadap perkembangan produk dan jasa keuangan. Selain itu, orang tua juga harus memberikan contoh secara langsung. Tujuan adanya catatan atau pembukuan tersebut sebenarnya bertujuan agar anak tidak boros dalam pengeluaran (berperilaku konsumtif). Hal tersebut sejalan dengan pernyataan Dewi (2017) yaitu perilaku konsumtif merupakan kegiatan konsumsi yang tidak didasarkan pada kebutuhan tetapi pada keinginan dan kepuasan semata. Jadi, sebagai orang tua harus mengajarkan anak untuk dapat menyesuaikan pengeluaran sesuai dengan kebutuhannya, tidak selalu menuruti apa yang menjadi keinginan anak. Agar anak tidak berperilaku konsumtif dan segala pengeluarannya dapat terkontrol dengan baik.

\subsubsection{Penerapan Nilai-nilai Pendidikan Ekonomi Keluarga Melalui Semangat Berwirausaha}

Para informan sebagai pelaku UMKM memiliki pengetahuan dan keterampilan kewirausahaan dalam dirinya. Begitupun dengan anak informan yang juga secara tidak langsung memiliki pengetahuan tentang nilai-nilai kewirausahaan yang diperoleh dari orang tuanya yang dapat diaplikasikan secara langsung di lapangan. Proses kewirausahaan yang ada 
di lingkungan keluarga masyarakat pelaku UMKM ini salah satunya disebabkan karena adanya tuntutan perekonomian. Menurut penelitian yang dilakukan oleh Bosma, et al., (2011), munculnya seorang wirausaha dikarenakan ada beberapa sebab, diantaranya karena adanya tekanan ekonomi yang menyebabkan seseorang terpaksa menciptakan lapangan pekerjaannya sendiri dengan keterampilan yang mereka miliki. Tekanan ekonomi juga disebabkan karena pengangguran dan adanya trauma dari pekerjaan sebelumnya. UMKM yang berkembang di Indonesia merupakan salah satu upaya untuk mengatasi tekanan ekonomi tersebut. UMKM saat ini juga lebih banyak mengarah kepada sektor ekonomi kreatif yang sangat ditentukan oleh modal manusia. Proses pengembangan semangat wirausaha yang dilakukan oleh pelaku UMKM di dusun Rejoso ini yaitu dengan mengajak anak dalam pekerjaan orang tua agar anak mengerti susahnya mencari pekerjaan dan agar bisa hidup mandiri. Orang tua mengajak anak untuk membantu pekerjaan orang tua sebagai upaya mengembangkan semangat kewirausahaan kepada anak. Semua informan sudah melibatkan anak dalam usaha keluarga dan empat informan sudah memberikan gaji seperti halnya karyawan yang lain. Satu dari empat informan bahkan mengajarkan anak untuk disiplin dan bertanggung jawab sebelum memegang usaha sendiri dengan memperkerjakan anak informan ke orang lain. Hal tersebut sejalan dengan teori Alfiah (2015) yaitu terdapat beberapa cara dalam menanamkan nilai-nilai kewirausahaan kepada anak diantaranya melalui kebiasaan atau kegiatan sederhana yang orang tua berikan setiap harinya seperti mengajarkan anak untuk disiplin, jujur, bertanggung jawab, berani mengambil resiko dan mempunyai jiwa kreatif dan inovatif.

Dalam penanaman nilai-nilai kewirausahaan ini, anak juga memiliki kesadaran untuk membantu orang tuanya dalam bekerja sehingga anak terbiasa untuk mandiri dan bisa mengerjakan pekerjaan apapun. Anak dapat mempraktekkan secara langsung sesuai dengan apa yang orang tua contohkan melalui usaha yang dimiliki. Setelah anak melakukan praktek kewirausahaan, secara tidak langsung anak telah belajar dan memiliki keberanian serta kepercayaan diri untuk terjun ke dalam dunia kewirausahaan seperti orang tuanya. Penelitian tersebut dapat dibandingkan dengan hasil yang hampir serupa yaitu dengan adanya praktik kewirausahaan yang dilakukan secara langsung di dalam usaha keluarga dapat menjadikan anak memiliki bekal untuk menjadi seorang pebisnis atau wirausaha dan atas kemauannya sendiri dapat terjun ke dalam dunia kewirausahaan (Asmawan, 2017).

Seorang wirausaha harus mempunyai sikap kewirausahaan yang mulai dibentuk sejak dini. Sikap kewirausahaan yang dibentuk tidak dapat terjadi dalam waktu yang singkat. Namun memerlukan waktu seiring dengan proses perkembangannya. Tujuan dari adanya pengenalan dan pembentukan sikap kewirausahaan yang dilakukan oleh orang tua kepada anak sebenarnya bukan untuk menjadikan anak menjadi seorang pengusaha. Melainkan pembentukan nilai-nilai kewirausahaan akan sangat bermanfaat bagi perkembangan keterampilan anak terlepas dari keinginan anak untuk menjadi pengusaha atau tidak. Anak akan belajar banyak hal dan terbentuknya sikap mental yang kuat yang akan bermanfaat ketika anak menjadi dewasa dan berhadapan dengan dunia kerja. Anak juga menjadi lebih percaya diri, mempunyai komitmen dan optimisme yang tinggi, serta memiliki inisiatif dan berani mengambil resiko (Suranto \& Dwi, 2018). Meskipun anak ikut membantu dalam bisnis orang tua atau pekerjaan orang tua, namun para informan tidak pernah memaksakan keinginan anak untuk meneruskan bisnis keluarga. Informan sebagai orang tua hanya dapat memberikan skill dan jiwa entrepreneur untuk bekal anaknya dalam mencari pekerjaan kelak. Menurut Ningrum (2017: 31) wirausaha adalah seseorang yang mengembangkan ide untuk melakukan upaya kreatif dan inovatif guna menemukan peluang yang bertujuan untuk meningkatkan taraf 
hidupnya. Seperti halnya masyarakat di kampung UMKM ini yang mengembangkan usahanya untuk kesejahteraan hidup keluarga. Kreatifitas dan keterampilan yang diperoleh sudah didapatkan secara turun-temurun.

\section{Simpulan}

\subsection{Kesimpulan}

Nilai-nilai pendidikan ekonomi keluarga belum sepenuhnya diterapkan dengan baik oleh keluarga pelaku UMKM di kampung UMKM Junrejo, Batu. Pengelolaan keuangan beberapa keluarga di kampung UMKM belum sepenuhnya dilakukan dengan maksimal. Namun, informan melakukan pencatatan keuangan mulai dari pencatatan semua pemasukan dan pengeluaran, identifikasi pengeluaran rutin, bulanan, dan tahunan setiap keluarga, menyusun rencana pengeluaran (budgeting), dan membagi setiap pendapatan ke dalam pospos untuk berbagai macam kebutuhan. Dalam pemberian uang saku, orang tua sudah cukup baik dalam penanaman pendidikan ekonomi kepada anak dibuktikan dengan tetap memberikan uang saku kepada anak pada masa pandemi dengan alasan pemberian uang saku merupakan kewajiban orang tua kepada anak. Begitupun dalam penanaman hidup hemat \& menabung yang sudah diterapkan dengan baik. Dibuktikan dengan anak informan yang tetap menabung dari hasil membantu usaha orang tua dikarenakan mereka tidak mendapatkan uang saku secara penuh ketika belajar di rumah.

Dalam hal berkonsumsi, anak informan sudah diajarkan untuk membuat catatan pengeluaran ataupun pemasukan setiap hari, setiap minggu atau setiap bulan meskipun terkadang tidak rutin. Sehingga dapat disimpulkan bahwa orang tua sudah menerapkan salah satu nilai pendidikan ekonomi dengan baik. Begitupun dengan pengembangan semangat wirausaha yang dilakukan dengan mengajak anak untuk ikut serta dalam pekerjaan orang tua, melibatkan anak dalam usaha keluarga dan memberi gaji seperti halnya karyawan yang lain. Sehingga orang tua sudah maksimal dalam mengajarkan anak untuk menerapkan nilai-nilai pendidikan ekonomi di lingkungan keluarga dalam hal kewirausahaan.

\subsection{SARAN}

Berdasarkan hasil penelitian yang telah dilakukan, maka saran yang dapat diberikan oleh peneliti adalah sebagai berikut: (1) Masyarakat pelaku UMKM di Dusun Rejoso diharapkan dapat meningkatkan pengetahuan mengenai nilai-nilai pendidikan ekonomi di dalam keluarga dan menerapkannya dalam kehidupan sehari-hari. Orang tua hendaknya mulai mengajarkan anak mengenai pentingnya pendidikan ekonomi di dalam keluarga sehingga pandemi tidak menjadi penghalang untuk terus berproduksi dan mencukupi kebutuhan hidup sehari-hari. (2) Bagi pemerintah desa Junrejo, diharapkan dapat membantu masyarakat dalam mengembangkan usaha yang dimiliki dengan mensosialisasikan pentingnya pendidikan ekonomi keluarga yang perlu untuk diterapkan dengan baik terutama pada saat pandemi seperti saat ini. (3) Bagi peneliti selanjutnya, diharapkan mampu mengembangkan hal-hal yang belum ada dalam penelitian ini dengan menggali hal-hal yang perlu untuk dianalisis secara mendalam terutama mengenai pendidikan ekonomi keluarga.

\section{Daftar Rujukan}

Alam S, (2013). EkonomiUntuk SMA/MA Kelas X. Jakarta: Erlangga 
Alfiah, Nur. (2015). Pendidikan Karakter Kewirausahaan Anak Di Kompleks Pasar Sudu Kelurahan Kambiolangi Kabupaten Enrekang.

Andrew, V., \& Linawati, N. (2014). Hubungan faktor demografi dan pengetahuan keuangan dengan perilaku keuangan karyawan swasta di Surabaya. Finesta, 2(2), 35-39

Ardiana, M. (2017). Kontrol Diri, Pendidikan Pengelolaan Keuangan Keluarga, Pengetahuan Inklusi Keuangan Siswa Pengaruhnya terhadap Perilaku Menabung Siswa SMK Se Kota Kediri. Jurnal Ekonomi Pendidikan dan Kewirausahaan, 4(1), 59-75.

Asmawan, M. (2017). Dampak mata kuliah praktek kewirausahaan terhadap motivasi mahasiswa pendidikan akuntansi untuk berwirausaha.

Ayuningtyas, T. (2014). Pengaruh pendidikan ekonomi di keluarga, pembelajaran ekonomi di sekolah terhadap perilaku konsumsi yang dimediasi oleh prestasi belajar (studi pada siswa SMA Negeri kelas XI IPS se Kabupaten Lumajang) (Doctoral dissertation, Universitas Negeri Malang).

Bank Indonesia. (2015). Pengelolaan Keuangan. .Grup Pengembangan Keuangan Inklusif Departemen Pengembangan Akses Keuangan Dan Umkm Bank Indonesia.

Bosma, N., Wennekers, S., \& Amorós, J. E. (2011). Extended report: Entrepreneurs and entrepreneurial employees across the globe. London (GB): Global Entrepreneurship Research Association.

Brief. (2012). Youth Financial Inclusion: Complementing Financial Education with Account Access. Journal for financial security, Vol. 5 No. 1, (PP: 1-4).

Dewi, N., \& Rusdarti, R. (2017). Pengaruh Lingkungan Keluarga, Teman Sebaya, Pengendalian Diri dan Literasi Keuangan Terhadap Perilaku Konsumtif Mahasiswa. Journal of Economic Education, 6(1), 29-35.

Fadila, R. U. (2020). 1.785 Koperasi dan 163.713 UMKM Terdampak Pandemi Covid-19: https://www.pikiranrakyat.com/ekonomi/pr-01379615/1785-koperasi-dan-163713-umkm-terdampak-pandemi-covid$\underline{19}$

Hadley, J. (2011). Mengelola Uang Saku. Jakarta: Pakar Raya

Harsono, H., \& Budiyanto, S. M. (2015). Membidik Mahasiswa Sebagai Calon Wirausahawan. Jurnal Pendidikan Ilmu Sosial, 25(2), 34-45.

Hasan, M. (2016). Pengembangan pola pendidikan ekonomi informal sebagai upaya untuk pembentukan perilaku ekonomi yang baik. In Prosiding Seminar Nasional" Mega Trend Inovasi dan Kreasi Hasil Penelitian dalam menunjang Pembangunan Berkelanjutan" hal (pp. 82-87).

Kamus, T. P. (2015). Besar Bahasa Indonesia, Kamus Besar Bahasa Indonesia.

Lail, J. (2015). Program Sentono Menabung. Asian Journal of Innovation and Entrepreneurship, 4(01), 54-57.

Marteniawati, R. (2012). Mental Accounting dalam Pengelolaan Uang Saku Pada Mahasiswa Universitas Kristen Satya Wacana. Salatiga: Universitas Kristen Satya Wacana.

Narmaditya, B. S. (2013). Pengaruh Pendidikan Ekonomi Keluarga Terhadap Perilaku Konsumsi Dimediasi Literasi Ekonomi dan Gaya Hidup Pada Mahasiswa Fakultas Ekonomi Universitas Negeri Malang Angkatan 2011. Ekuitas: Jurnal Pendidikan Ekonomi, 1(1).

Nasional, K. P. (2010). Universitas Negeri Malang. Pedoman Penulisan Karya Ilmiah. Edisi ke lima.

Ningrum, M. A. (2017). Peran keluarga dalam menumbuhkan jiwa wirausaha sejak usia dini. JP (Jurnal Pendidikan): Teori dan Praktik, 2(1), 39-43.

Rapih, S. (2016). Pendidikan Literasi Keuangan Pada Anak: Mengapa dan Bagaimana?. Scholaria: Jurnal Pendidikan dan Kebudayaan, 6(2), 14-28.

Silvy, M., \& Yulianti, N. (2013). Sikap pengelola keuangan dan perilaku perencanaan investasi keluarga di Surabaya. Journal of Business and Banking, 3(1), 57-68.

Soemanagara, D. F. (2019). Kampung UMKM Batu Masih Butuh Dukungan Berbagai Pihak: https://mnews.co.id/read/fokus/kampung-umkm-batu-masih-butuh-dukungan-berbagai-pihak/

Sugiyono. (2017). Metode Penelitian Kuantitatif, Kualitatif dan R\&D. Bandung. Alfabeta

Sulaeman, D. Humalik. (2012). Psikologi Remaja Dimensi-Dimensi Perkembangan. Bandung : CV. Mandar Maju.

Suryani, I. (2018). Pentingnya pendidikan informal tentang ekonomi pada keluarga transmigran. Jurnal Teori dan Praksis Pembelajaran IPS, 2(2), 94-100. 
Utami, S. D., \& Suranto, S. P. (2018). Pembentukkan Karakter Entrepreneurship dalam Mata Kuliah Praktek Kewirausahaan pada Mahasiswa Pendidikan Akuntansi angkatan 2014 (Doctoral dissertation, Universitas Muhammadiyah Surakarta).

Vhalery, R., Leksono, A. W., \& Irvan, M. (2019). Pengaruh Literasi Keuangan, Usia, dan Bimbingan Orang Tua terhadap Pengelolaan Uang Saku Mahasiswa UNINDRA. Jurnal Pendidikan Ekonomi, 12(1), 10-17.

Vito, I. (2013). Pengaruh Pendidikan Ekonomi di Lingkungan Keluarga Terhadap Rasionalitas Ekonomi Mahasiswa Pendidikan Ekonomi FKIP Universitas Tanjungpura. Jurnal Pendidikan dan Pembelajaran Khatulistiwa, 2(6).

Widayati, I. (2012). Pengaruh Status Sosial Ekonomi Orang Tua, Pendidikan Pengelolaan Keuangan Keluarga, dan Pembelajaran di Perguruan Tinggi Terhadap Literasi Finansial Mahasiswa Fakultas Ekonomi dan Bisnis Universitas Brawijaya. (Tesis). DISERTASI dan TESIS Program Pascasarjana UM.

Widyawati, I. (2012). Faktor-faktor yang mempengaruhi literasi finansial mahasiswa fakultas ekonomi dan bisnis Universitas Brawijaya. Assets: Jurnal Akuntansi dan Pendidikan, 1(1), 89-99.

Wirjono, E. R., \& Raharjono, A. B. (2012). Survei pemahaman dan pemanfaatan informasi akuntansi dalam usaha kecil menengah di Daerah Istimewa Yogyakarta. AUDI Jurnal Akuntansi dan Bisnis, 7(2). 